\title{
Agri-environment schemes are associated with greater terrestrial invertebrate abundance and richness in upland grasslands
}

\author{
Amy Arnott $^{1}$ (D) $\cdot$ Gillian Riddell $^{1} \cdot$ Mark Emmerson $^{1} \cdot$ Neil Reid $^{1}$ (D)
}

Accepted: 3 November 2021 / Published online: 18 January 2022

(c) The Author(s) 2022

\begin{abstract}
Agri-environment schemes are a key mechanism by which agricultural sustainability is encouraged by subsidising farmers to adopt environmentally friendly management (e.g. reduction of inputs) to maintain and enhance the delivery of biodiversityassociated ecosystem services. Studies testing the efficacy of agri-environment schemes have yielded varying results, and few have focused on upland (marginal or Less Favoured Area) grassland ( $>150 \mathrm{~m}$ above sea level) where productivity is poor. This study used a factorial field experiment to examine patterns in plant communities and terrestrial invertebrates between agri-environment scheme and conventionally managed semi-improved and improved upland grasslands, using 90 spatially paired fields. Total plant species richness and rare plant species richness (those with $<10 \%$ occurrence) were unaffected by agri-environment scheme management, but were significantly higher on semi-improved than improved grasslands. Total and rare invertebrate abundance and family-level richness were unrelated to grassland type (semi-improved or improved). Total and rare invertebrate abundances were $4 \%$ and $218 \%$ higher, and total and rare invertebrate family-level richness were $17 \%$ and $14 \%$ higher in agri-environment scheme than conventionally managed fields, respectively. Here, we show that agri-environment scheme management of marginal or Less Favoured Area upland grassland was associated with higher multi-taxa invertebrate abundance and richness associated with swards indicative of wetter conditions with lower dominance of perennial ryegrass (Lolium perenne) and greater coverage of other native grass species compared to conventional management. This suggests that agri-environment schemes may maintain, enhance or offset declines in terrestrial invertebrates and their associated ecosystem service delivery by maintaining more diverse swards, and suggests that they make a positive contribution to biodiversity conservation.
\end{abstract}

Keywords Biodiversity · Conservation · Extensification · Farmland · GLMM · Intensification · Land management · Terrestrial invertebrates $\cdot$ Pitfall trapping

\section{Introduction}

Agricultural production has been predicted to double by 2050 (Tilman 1999; Butler et al. 2007), raising the extinction risk of species that dwell in farmland habitat. The demand to feed a rapidly increasing human population will require that sustainability is explicitly incorporated into agricultural practices to enhance ecosystem service provision by biodiversity and to lower agriculture's environmental footprint (Chapin III et al. 2000; Loreau et al. 2001; Foley et al.

Amy Arnott

aarnott01@qub.ac.uk

1 Institute of Global Food Security (IGFS), School of Biological Sciences, Queen's University Belfast, Belfast BT9 5DL, UK
2005). Biodiversity-associated ecosystem service delivery is compromised by homogeneity and intensification of land use (Altieri 1999). Fragmentation and degradation of semiimproved and natural habitat remain the principal drivers of species extinction in developed nations (Thomas et al. 2004), and the continued intensification of agriculture is a major contributor to the current global biodiversity crisis (Chapin III et al. 2000; Barnosky et al. 2011; Ceballos et al. 2017). Invertebrates comprise around $80 \%$ of all described species (Cardoso et al. 2011), yet in some regions, for example Germany, there has been a 75\% decline in aerial insect biomass over the last 30 years (Hallmann et al. 2017). Others predict a ca. $40 \%$ decline in insects globally with declines up to $60 \%$ in the UK (Sánchez-Bayo and Wyckhuys 2019). It has been reported that invertebrates have undergone large declines not just in biomass, but also in habitats occupancy, in contrast 
with other taxonomic groups (Outhwaite et al. 2020). These estimates are not without controversy, with some reviews listing examples of increases and decreases, e.g. for moths (Macgregor et al. 2019), suggesting a more nuanced interpretation is required for quantifying abundance or diversity change, with species-specific responses linked to climate or land-use changes (Fox et al. 2014). It is clear that one of the greatest impacts on terrestrial invertebrate biodiversity is the intensification of agriculture and the conversion of semi-natural habitats to homogeneous farmland including grasslands (Tscharntke et al. 2005; Fritch et al. 2017).

Invertebrates serve as potential bioindicators of ecosystem function (Spafford 2013) and encompass a wide range of trophic guilds, with subsequent functional diversity leading to the regulation and provision of ecosystem services. Many ecosystem functions and services are required for aboveground net primary productivity, such as nutrient assimilation by plants, decomposition and recycling of above- and belowground resources, increased carbon sequestration, pollination, pest biocontrol and maintenance of soil structure and prevention of erosion (Prather et al. 2013). Even small changes in diversity or abundance of invertebrates in grasslands can substantially alter (agro)ecosystem functioning (Soliveres et al. 2016). Consequently, conservation-focused management interventions that are designed to increase sustainable food production must account for multiple rather than a few focal trophic groups.

Grasslands occupy almost $40 \%$ of terrestrial land cover in the UK (Office for National Statistics 2015). In marginal upland areas (defined as $>150 \mathrm{~m}$ above sea level in the region of Northern Ireland), grassland is classified as either 'semi-improved' (moderate biodiversity) or 'improved' (low biodiversity), depending on management intensity (Fig. 1). Semi-improved grassland habitat is moderately species-rich due to lower inputs of fertiliser and contains $<25 \%$ sown species (e.g. perennial ryegrass Lolium perenne and white clover Trifolium repens) with a high percentage of native grasses maintained by long-term extensive grazing (DAERA 2007). Improved grasslands are species-poor due to high inputs of fertiliser and contain $>25 \%$ sown species with a low percentage of native grasses maintained by intensive grazing with periodic rejuvenation by ploughing and reseeding (DAERA 2007).

Upland grassland pastures are used for livestock rearing and fodder production and are often termed 'Less Favoured Areas' (LFAs), due to poor productivity. Nevertheless, these habitats are significant agricultural landscapes that comprise the majority (51\%) of agricultural land in the UK (DAERA 2018a) and are notably important in sustaining biodiversity, depending on their management regime (Acs et al. 2010; Sánchez-Bayo and Wyckhuys 2019). Lower productivity of upland farms in LFAs means farmers are dependent on subsidies and environmental-based payments under the

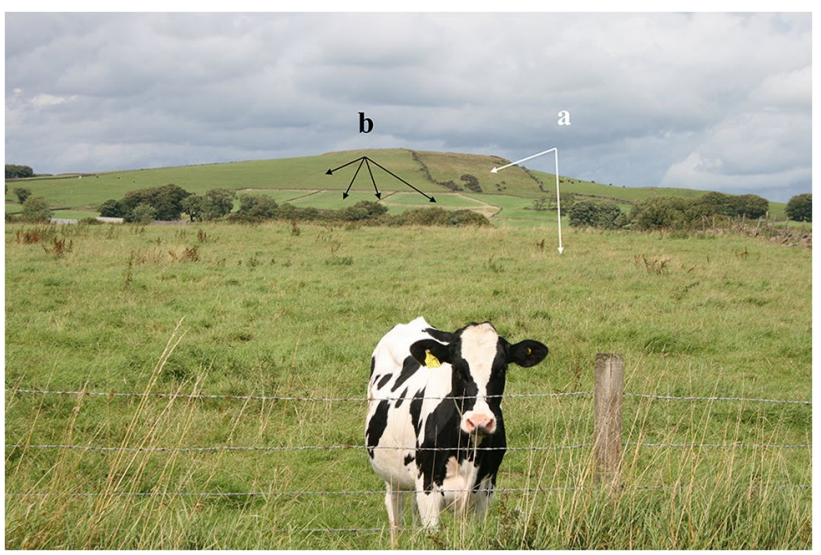

Fig. 1 Agricultural grassland in upland fields, characterised by moderate plant biodiversity, semi-improved (a) and low plant biodiversity and improved grassland (b). Photograph by Amy Arnott.

Common Agricultural Policy (CAP), including agri-environment schemes, hereafter referred to as AESs (Acs et al. 2010).

Ecologically orientated AES management is generally employed at the field level and intended to maintain and increase biodiversity (Concepción et al. 2008). Contrary to conventional management, AES management practices focus on reducing artificial inputs (fertilisers and pesticides), extensifying management practices, e.g. delaying mowing or reducing livestock grazing density whilst increasing areas of semi-natural habitat, e.g. maintaining or enhancing hedgerows. Farmers and landowners are subsidised for any potential loss in productivity using financial incentives which are particularly valuable for those farming marginal or Less Favoured Areas. Through long-term AES management, biodiversity-poor improved grasslands can be restored enhancing biodiversity and ecological integrity with notable benefits for farmland specialist species (Woodcock et al. 2010; Steiner et al. 2016). However, the efficacy of AESs for biodiversity conservation is highly variable differing between species (Reid et al. 2007; Arnott et al. 2021) and prevailing management systems. Most studies have focussed on assessing AESs with respect to plant, pollinator and bird species richness (Kleijn and Sutherland 2003; Haaland et al. 2011; Kampmann et al. 2012). Others single out key indicator taxa such as predatory spiders or ground beetles (Batáry et al. 2012; Gallé et al. 2018). Comparisons are often made between field edge margins (the focus of most AESs) and the centre of fields where intensive management is greatest, particularly in cropland (e.g. Kovács-Hostyánszki et al., 2011; Batáry et al., 2015). Although there have been studies assessing AES impacts in grasslands more generally (e.g. Caruso et al. 2015; Berg et al. 2019; Jakobsson et al. 2019), there are a paucity of data spanning the diversity of whole invertebrate taxonomic groups (e.g. Smith et al., 2008), 
and still fewer studies have assessed the impact of AESs on marginal farmland; specifically, few invertebrate multi-taxa studies have been conducted in intensively grazed improved grasslands (where the benefits of AESs are questionable) and compared to more species-rich, semi-improved grasslands in upland regions ( $>150 \mathrm{~m}$ above sea level).

This study aimed to assess the efficacy of AESs in marginal upland grasslands within the central portion of actively farmed fields where intensity is typically greatest. The specific objective was to assess terrestrial invertebrate richness and abundance, along with plant community composition. The focus was not taxa-specific, with richness and abundance assessed across all taxa trapped at the field surface, comparing AES impacts on semi-improved and improved grasslands using a factorial field experiment. It was hypothesised that invertebrate diversity and abundance would be (1) greater in semi-improved than improved grasslands and (2) that AES impacts would be greatest in improved grasslands where extensification had the greatest potential to effect invertebrate diversity and abundance.

\section{Methods}

\subsection{Study sites}

The study was conducted in County Antrim, Northern Ireland, whose landscape is characterised by marginal upland grassland (almost $70 \%$ of total land area) and where $<2 \%$ of agricultural land is managed under AESs (DAERA 2019). Paired field sites (Fig. S1) were selected from the UK Land Cover Map 2007 (Centre for Ecology \& Hydrology 2011) and an agri-environment scheme (AES) map provided by the Department of Agriculture, Environment and Rural Affairs (DAERA). Field land parcel polygons $>150 \mathrm{~m}$ above sea level restricted samples to upland regions only (following Flexen, O'Mahony and McAdam, 2013), with field habitat classification used to select between semi-improved and improved grasslands from the map. These were classed in the map by plant richness attributes (i.e. semi-improved grassland defined as $<25 \%$ sown species). Both were mowed, being harvested for silage, and grazed (most frequently after mowing) but at different intensities, i.e. improved grasslands would be mowed and grazed more frequently than semiimproved fields. Moreover, improved grasslands were renovated by herbicide application, ploughing and reseeding with perennial ryegrass Lolium perenne approximately every 3-5 years, whilst semi-improved grasslands were typically improved by fertiliser use and cutting but are not renovated on a rotational basis. AES fields were part of the Northern Ireland Countryside Management Scheme (NICMS) and had been part of the scheme for at least 5 years. The maximum allowable application of nitrogen is $250 \mathrm{~kg} \mathrm{~N}$ per ha per year for farms in the wider countryside (DAERA 2018b), though $90 \%$ of farms apply $<170 \mathrm{~kg} \mathrm{~N}$ per ha per year. The NICMS reduces this further to $25-100 \mathrm{~kg} \mathrm{~N}$ per ha per year, whilst measures focus on increasing areas of semi-natural habitat (e.g. sowing wildflowers, delaying mowing, increasing hedgerow length and quality and reducing livestock density). There are no limits on herbicide use for improved and semiimproved fields within the scheme.

Fields were selected only if they had $>3$ sides bordering another field with the same management (AES/conventional) and habitat (semi-improved/improved) in order to reduce edge effects. Areas that were managed specifically for high conservation value, such as Areas of Special Scientific Interest (ASSIs) and Special Areas of Conservation (SACs), were avoided in order to focus on AESs on active farms only. A total of 90 fields were surveyed: 45 AES fields (selected first) were paired with 45 conventionally managed fields). Sites ranged from 0.26 to 23 ha and were paired $<1 \mathrm{~km}$ distant with a similarly sized field ( $<2$ ha different in size) to reduce regional and spatial effects. Within each of the 45 AES or conventional fields, 21 were semi-improved grassland and 24 improved grassland. The disparity was caused by a lack of available semi-improved fields within a $<1 \mathrm{~km}$ buffer. Selected fields were imported into Google Earth, and a timeline of satellite imagery was used to determine past land use. Sites were only selected if they had been managed as farmed grassland for $>10$ years. If these fields did not meet requirements after inspections, alternative fields were chosen. Field use, habitat and management were groundtruthed by asking landowners and farmers before surveys began.

\subsection{Plant and invertebrate diversity}

Fields were sampled under dry weather conditions (between June and September 2018), with paired fields sampled within the same week of one another. Vegetation was sampled using a 50-cm gridded quadrat, placed randomly at three points in the centre of each field. Improved and semi-improved grasslands are highly even vegetative communities; thus, diversity was expected to be low (largely restricted to a few species of grass interspersed by weeds). This precluded the need for extensive characterisation of plant community composition by using large quadrats or high levels of within-field replication. Vegetation was recorded using modified UK National Plant Monitoring Scheme guidelines (NPMS 2015). The average vegetation height was recorded once during the sampling period using a sward stick, from five random height measurements within each quadrat. The percentage cover of each species was recorded, along with the percentage cover of bare ground, leaf litter and livestock dung. Dung density was taken as a proxy for grazing intensity. 
A single pitfall trap was placed at the centre of each field following Kleijn et al. (2006), and left for 1 week, and then emptied upon collection. Our objective was not to produce a definitive species list for sampled sites (e.g. an asymptotic species accumulation curve) but to provide a relative comparison of standardised samples within our key investigative factors of semi-improved vs improved grassland under AES vs conventional management. We prioritised maximising our sample size of independent sites (fields) over replication within fields. All fields were uniformly sampled providing directly comparable results for hypothesis testing; thus, low sample density (one plant quadrat and one invertebrate pitfall trap) should not have introduced bias or error with respect to the applied research questions being asked. Each pitfall trap consisted of a $9.0 \times 8.5-\mathrm{cm}$ plastic container filled with $60 \mathrm{ml}$ of propanediol: a non-toxic antifreeze agent commonly used for preservation. Each trap was protected from flooding by a plastic rain cover placed approximately $5 \mathrm{~cm}$ above each trap, and the traps were covered with chicken wire (13 $\mathrm{mm}$ mesh gauge) to prevent interference from small mammals. Farmers agreed to leave fields temporarily ungrazed to prevent damage to of traps. Specimens were preserved in $70 \%$ ethanol.

All adult invertebrates were identified to family-level only, following Chinery (1993) and Roberts (1995). The objective was not to produce a parochial species list per field, and without the time and expertise to identify each specimen to species-level, family was taken as the optimal taxonomic level to reduce misidentification and allow the work to be completed in a timely manner. Regardless, as all adult invertebrates were identified to the same taxonomic resolution, our results were relative between standardised samples of semi-improved and improved grasslands under AES or conventional management. Additionally, as paired fields were sampled simultaneously and controlled by introducing this as a random factor in all models, using familylevel taxonomic resolution should not have introduced bias or error in terms of comparing our key investigative factors.

\subsection{Statistical analysis}

Distance-based redundancy analysis (dbRDA) was used to reduce variation in plant community composition after Hellinger transformation. Permutational analysis of variance (ANOVAs) was used to test the significance and quantify the effects of all constraining variables (management, habitat and their interaction) within the dbRDA. General linear mixed models (GLMMs) were used to examine variation of the following response variables: dung density, sward height, invertebrate abundance, family richness and rare $(<10 \%$ occurrence $)$ invertebrate abundance and family richness. Each was fitted as the dependent variable tested a priori to define their distribution (either Gaussian, Poisson, zero-inflated Poisson or negative binomial). To account for site effects within management types (i.e. paired AES and conventional fields $<1 \mathrm{~km}$ apart), Field Pair_ID was fitted as a random factor controlling for commonalities in spatial location not quantified by explicitly measured explanatory variables. Furthermore, principal coordinates of neighbourhood matrix (PCNM) eigenvectors of the distance matrix of $X$ and $Y$ coordinates for each of the 90 fields were used to model potential spatial autocorrelation between pairs of fields and clusters of fields (following Borcard and Legendre, 2002; Maaß et al., 2014; Caruso et al., 2017). The PCNM axes that were significantly associated with variation in pitfall invertebrate community composition were retained in further analyses. Habitat, management and their interaction were fitted as fixed factors, and dbRDA and PCNM axes were fitted as covariates so that models followed the form of Response variable $\sim$ Habitat * Management + dbRDA axes + spatial PCNM axes + (1/PairID). Multicollinearity between explanatory variables was tested using the Pearson correlation coefficient and variance inflation factor (VIF) values indicated by the thresholds of $<10$ and $<0.7$, respectively (Zuur et al. 2010; Humphreys et al. 2019). If any set of collinear explanatory variables exceeded these thresholds, one of each set of significant bivariates was excluded from GLMM analysis. Multi-model comparison was used to select the best model ranked by Akaike information criterion values corrected for small sample sizes (AICc), where each model was ranked against global and null models and all plausible models. The top model was taken as that with the lowest AICc. Residuals were checked for normality demonstrating that the data met the assumptions of the test. To ensure our sample density was sufficient to demonstrate effects, we conducted a power analysis assuming our final sample sizes and model structure with the minimum effect size detectable at $80 \%$ power being $\leq 0.21$, generally characterised as a 'small' difference between groups (see Cohen, 1988). The estimated marginal mean values for the interaction of Habitat*Management were plotted for each model after environmental variation in plant communities were accounted for by fitting them at their average values. All analyses were performed using R (R Core Team 2018). Multivariate analyses were performed using prcomp in the package stats, GLMMs were performed using package glmmTMB (Brooks et al. 2016), PCNM analysis was performed using package vegan (Oksanen et al. 2019), and model selection was performed using package AICcmodavg (Mazerolle 2019).

\section{Results and discussion}

\subsection{Plant community}

A total of 33 plant species were recorded with perennial ryegrass Lolium perenne present in 93\% of fields (Table S2; Fig. 3). Dung density, taken as a proxy for livestock grazing intensity, 
was unaffected by habitat, management or their interaction (Table 1a). Sward height was significantly (10\%) taller in conventionally managed than AES fields (Table 1b; Fig. 2a). Plant species richness was significantly (32\%) higher, and rare plant species richness was also significantly (91\%) higher in semiimproved than improved grasslands (Table 1c, d; Fig. 2b, c).

A total of $17 \%$ of plant community composition was explained by the first two dbRDA ordination axes, suggesting weak structuring indicative of highly even communities (Table 2; Fig. 3). The first dbRDA axis had the lowest cover of perennial ryegrass and the highest cover of, for example, Sphagnum spp. mosses, crested dogstail Cynosurus cristatus and Yorkshire fog Holcus lanatus (= less intensively managed grassland), whilst the second axis had the lowest cover of Sphagnum spp. mosses and the highest cover of ryegrass, Yorkshire fog and broad-leaved dock Rumex obtusifolius (=more intensively managed). Permutational ANOVA tests to assess the significance of the constraining variables within the dbRDA axes suggested that grassland plant community composition varied between management $\left(F_{\mathrm{df}=1,86}=2.352\right.$, $p=0.014)$, habitat $\left(F_{\mathrm{df}=1,86}=11.718, p=0.001\right)$ and their interaction $\left(F_{\mathrm{df}=1,86}=4.011, p=0.001\right)$ (Table S3).

\subsection{Invertebrate community}

A total of 2,018 individual invertebrates belonging to 70 families (of which 45 were classed as 'rare', i.e. $<10 \%$ abundance) were identified (Table S1). Araneae (spiders) represented $4 \%$ of the total invertebrate families and were most

Table 1 Single best generalised linear mixed models for (a) dung density, (b) sward height, (c) plant species richness and (d) rare plant species richness. S.E. standard error.

\begin{tabular}{lrrl}
\hline $\begin{array}{l}\text { Model Distribution Explan- } \\
\text { atory variables }\end{array}$ & $\beta \pm$ S.E & \multicolumn{1}{l}{$Z$} \\
\hline (a) Dung density Negative binomial & & \\
Management, conventional & $0.214 \pm 0.518$ & 0.413 & 0.679 \\
Habitat, semi-improved & $0.897 \pm 0.507$ & 1.770 & 0.077 \\
Management*Habitat & $-0.914 \pm 0.686$ & -1.332 & 0.183 \\
(b) Sward height Negative binomial & & \\
Management, conventional & $0.270 \pm 0.128$ & 2.108 & 0.035 \\
Habitat, semi-improved & $-0.279 \pm 0.199$ & -1.401 & 0.161 \\
Habitat*Management & $-0.008 \pm 0.192$ & -0.044 & 0.965 \\
(c) Plant spp. richness Poisson & & & \\
Management, conventional & $-0.214 \pm 0.143$ & -1.493 & 0.135 \\
Habitat,semi-improved & $0.446 \pm 0.126$ & 3.540 & $>0.001$ \\
Management*Habitat & $0.014 \pm 0.188$ & 0.075 & 0.940 \\
(d) Rare plant spp. richness & & & \\
Management, conventional & $-0.406 \pm 0.646$ & -0.628 & 0.530 \\
Habitat-semi-improved & $1.674 \pm 0.450$ & 3.721 & $>0.001$ \\
Management*Habitat & $-0.442 \pm 0.731$ & -0.604 & 0.546 \\
\hline
\end{tabular}

abundant (869 individuals) with the Linyphiidae (money spiders) being the most common family. Coleoptera (beetles) had 12 families (16\%) and notably were also common (405 individuals). Diptera (flies) were the most taxon rich order with 24 families (34\%) but had lower abundance (355 individuals).

All invertebrate metrics exhibited significant spatial autocorrelation being negatively associated with PCNM2 (Table 3); thus, all plots of estimated marginal means neutralised this effect by fitting PCNM2 at its average value when assessing management and habitat effects (Fig. 2). Accounting for spatial autocorrelation, total and rare invertebrate abundance were both negatively associated with conventional management (Table $3 \mathrm{a}, \mathrm{b}$ ) being $4 \%$ and $218 \%$ higher in AES fields, respectively, although large \% differences were driven by a small actual number increase (Fig. 2d, e), whilst total abundance was positively associated with plant dbRDA axis 2 (Table 3)a, b. More invertebrates were found in plant communities with lower dominance of ryegrass and greater coverage of native grasses, such as Yorkshire fog (Holcus lanatus). Total and rare invertebrate family richness were both negatively associated with conventional management (Table 3c, d) being $17 \%$ and $14 \%$ higher in AES fields, respectively (Fig. 2f, g). We accept hypothesis 1 that plant and invertebrate diversity is greater in semi-improved than improved grasslands but reject hypothesis 2 that AES impacts would have greatest effect in improved grasslands where extensification had the greatest potential to effect invertebrate diversity and abundance. The effect of agri-environment scheme management was consistent between grassland types.

\subsection{Agri-environment scheme management and habitat effects}

Improved and semi-improved grasslands are dominated by perennial ryegrass (Lolium perenne), which is the most commonly sown agricultural grass with greater cover (near monoculture) in improved grasslands. Such grasslands are typically drained, rejuvenated regularly by ploughing and reseeding, and receive annual applications of fertiliser, usually in the form of slurry. Semi-improved grassland swards, whilst still dominated by ryegrass, also contain native grasses, sedges, mosses and weeds indicative of wetter conditions associated with less drainage. Semiimproved grasslands are infrequently or never reseeded but might receive fertilisation albeit less frequently than improved grassland (given the wetter conditions). Semiimproved grasslands are usually grazed with lower livestock densities which may also encourage species-rich swards by creating a more heterogeneous structure (Marrs et al. 2004; Fraser et al. 2009). In contrast, improved grasslands are either intensively grazed or regularly 
a)

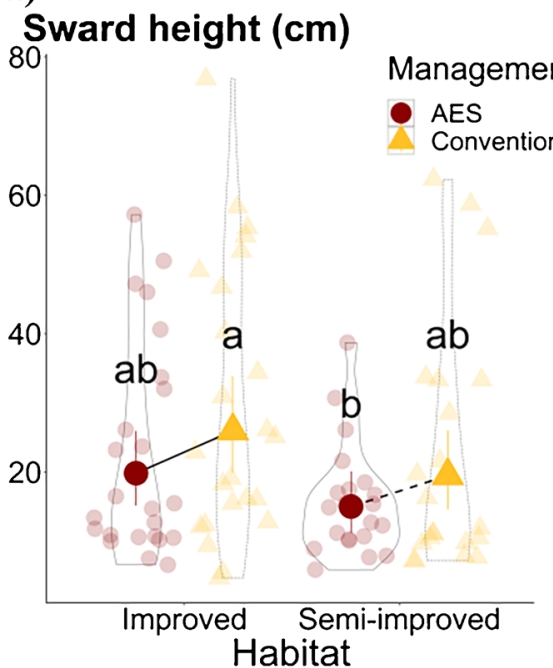

d)

Invert. Abundance

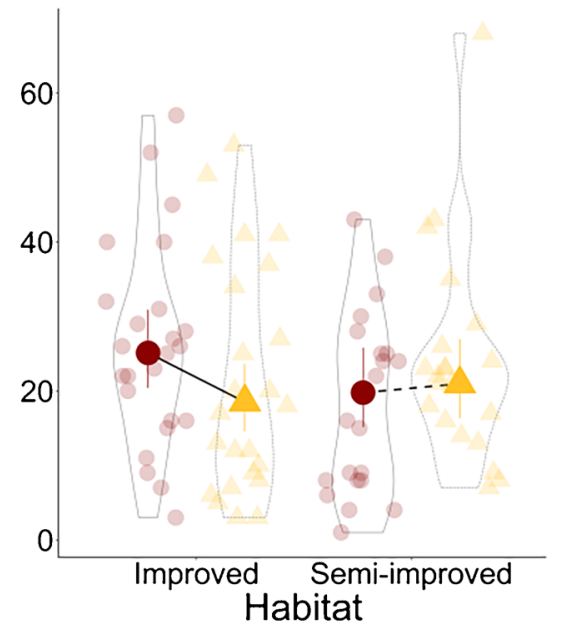

g)

Rare Invert. Richness

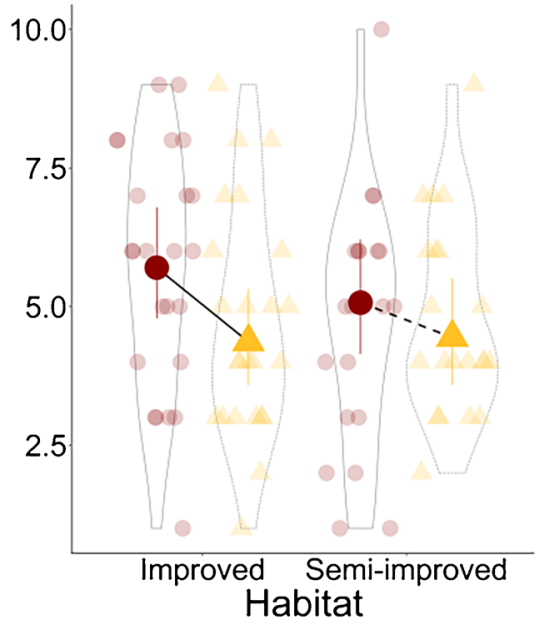

b)

Plant sp. Richness

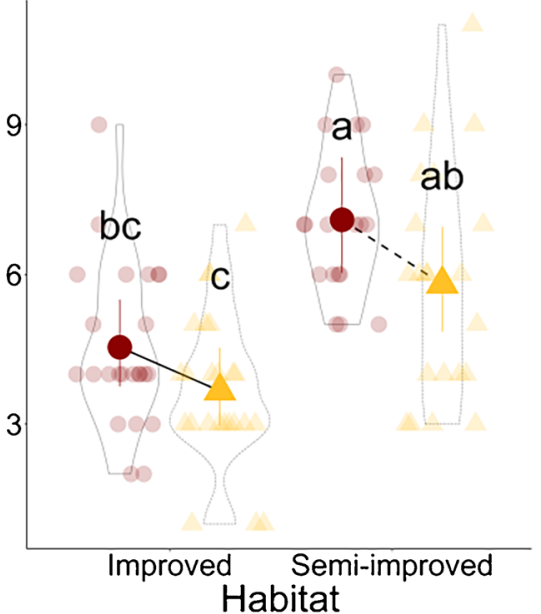

e)

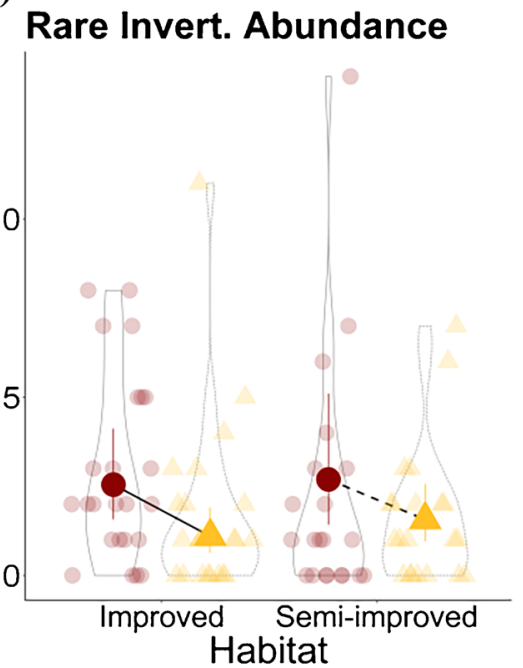

c)

Rare Plant sp. Richness

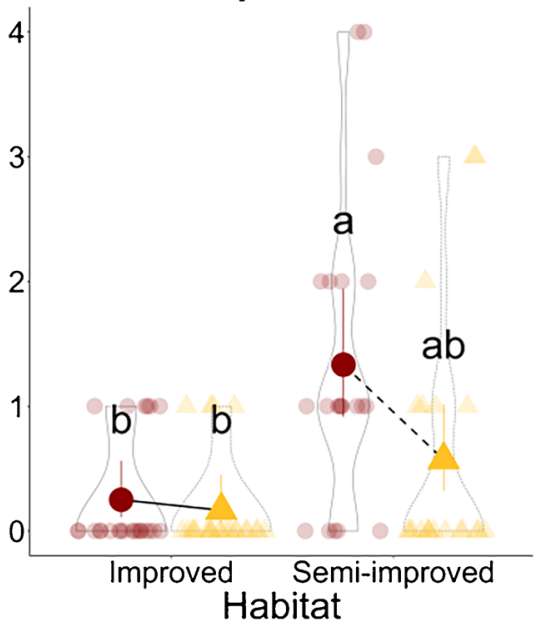

f)

Invert. Richness

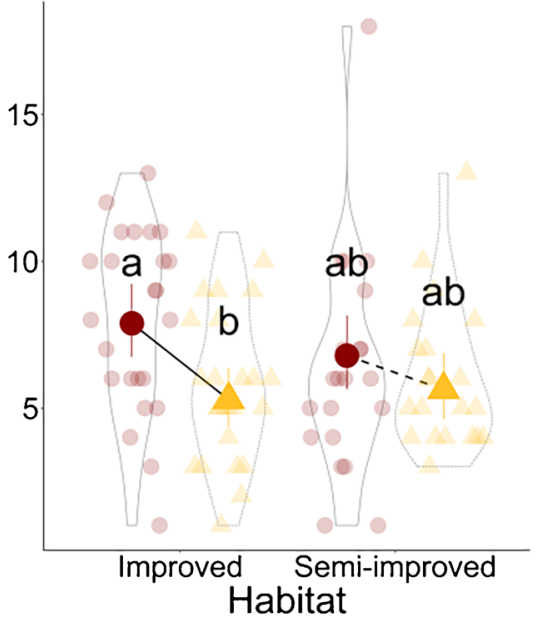


४Fig. 2 Violin plots showing data density and spread of generalised linear mixed model (GLMM) estimated marginal (predicted) means (EMM) values for (a) sward height, (b) plant species richness, (c) rare $(<10 \%$ occurrence) plant species richness, (d) invertebrate abundance, (e) rare invertebrate abundance invertebrate, (f) invertebrate family richness and (g) rare invertebrate family richness. Significant differences between EMM categories are shown by letter notation above.

harvested for fodder in the form of silage creating more homogenous swards. Nevertheless, in this study, dung densities that were measured as a potential proxy for grazing density did not differ significantly between semi-improved and improved grasslands; although positively associated with semi-improved grassland, this was not significant $(p=0.077)$. It may be that conventional and improved grassland fields were used for forage more often than livestock extensive grazing. If harvested for silage, grass is typically allowed to grow long prior to harvest resulting in increased sward heights as observed here. The resulting competition might reduce plant species richness in favour of fast growing ryegrass (Jefferson 2005). However, the timing of harvesting went unmeasured in this study, and as such, we cannot definitively state that it is a direct result of management actions.
Table 2 Distance-based redundancy analysis (dbRDA) of vegetation coverage.

\begin{tabular}{|c|c|c|c|}
\hline Ordination metrics & & Axis 1 & Axis 2 \\
\hline Eigenvalues & & 5.999 & 0.653 \\
\hline$\%$ variance & & 15.1 & 1.6 \\
\hline Cumulative $\%$ variance & & 15.1 & 16.8 \\
\hline Common name & Latin name & Axis loadings & \\
\hline Perennial ryegrass & Lolium perenne & -1.842 & 0.217 \\
\hline Yorkshire fog & Holcus lanatus & 1.239 & 0.597 \\
\hline Crested dogstail & Cynosurus cristatus & 1.113 & 0.052 \\
\hline Creeping buttercup & Ranunculus repens & 0.535 & 0.169 \\
\hline White clover & Trifolium repens & 0.260 & -0.219 \\
\hline Broad-leaved dock & Rumex obtusifolius & -0.164 & 0.495 \\
\hline Timothy grass & Phleum pratense & -0.432 & -0.078 \\
\hline Meadow foxtail & Alopecurus pratensis & -0.421 & -0.198 \\
\hline Annual meadowgrass & Роа аппиа & -0.035 & -0.123 \\
\hline Common bent grass & Agrostis capillaris & 0.255 & -0.111 \\
\hline Common chickweed & Stellaria media & -0.011 & 0.002 \\
\hline Common mouse-ear & Cerastium fontanum & -0.330 & -0.062 \\
\hline Common couch & Elymus repens & -0.007 & 0.065 \\
\hline Daisy & Bellis perennis & -0.051 & -0.029 \\
\hline Oxeye daisy & Leucanthemum vulgare & 0.069 & -0.030 \\
\hline Meadow thistle & Cirsium dissectum & 0.082 & -0.076 \\
\hline Sphagnum moss & Sphagnum (genus) & 1.074 & -0.266 \\
\hline Soft rush & Juncus effusus & 0.669 & -0.167 \\
\hline Hard rush & Juncus inflexus & 0.176 & 0.037 \\
\hline Mat grass & Nardus stricta & 0.387 & -0.171 \\
\hline Tufted hair grass & Deschampsia cespitosa & 0.124 & -0.013 \\
\hline Purple moor-grass & Molinia caerulea & 0.155 & -0.069 \\
\hline Devil's-bit scabious & Succisa pratensis & 0.055 & -0.024 \\
\hline Lady's thumb smartweed & Persicaria maculosa & -0.104 & -0.037 \\
\hline Eyebright & Euphrasia (genus) & 0.004 & 0.039 \\
\hline Marsh lousewort & Pedicularis palustris & 0.028 & -0.012 \\
\hline Star sedge & Carex echinata & 0.100 & -0.044 \\
\hline Common nettle & Urtica dioica & 0.003 & 0.029 \\
\hline Yarrow & Achillea millefolium & 0.180 & 0.112 \\
\hline Dandelion & Taraxacum officinale & 0.106 & -0.047 \\
\hline Ribwort plantain & Plantago lanceolata & 0.008 & 0.081 \\
\hline Marsh horsetail & Equisetum palustre & 0.031 & -0.013 \\
\hline Marsh arrowgrass & Triglochin palustris & 0.031 & -0.013 \\
\hline
\end{tabular}


Multivariate analysis suggested that a considerable portion of variation in plant community composition was left unexplained, suggesting that unmeasured environmental variables as well as a number of local scale processes might play a significant role in determining community patterns. Extending the number of quadrats used to sample may alleviate this in the future. Nevertheless, agricultural grasslands are highly even, homogenous communities compared to highly rich and diverse set-aside areas or areas of Special Scientific Interest, so low structuring (limited covariance between species) is to be expected. Nevertheless, statistical modelling suggested that habitat rather than management was the main driver in differences between the plant communities indicative of their intensification over the long-term (grasslands in this study were at least 10 years old). Notably, AES management as part of the Northern Ireland Countryside Management Scheme (NICMS) was in place for a minimum of 5 years, whilst more generally, AESs do not run for more than 10 years (Lennox and Armsworth 2011).

Total and rare invertebrate abundances and family-level richness were unrelated to grassland type (improved or semiimproved) but were all significantly higher in AES than conventionally managed fields associated with swards indicative of wetter conditions with lower dominance of ryegrass and greater coverage of native grasses suggestive of lower intensity management. Although the results have shown clear effects of management on invertebrate biodiversity, we cannot conclude this as a causative relationship without before-andafter data. Other processes, such as seasonal and micro-climate variation in invertebrate communities, may also play a large role in dictating abundance and diversity. Additionally, other measures such as artificial intelligence or genetic metabarcoding techniques could serve as species identification tools which could reduce variation in future studies.

Carabidae ground beetles and Staphylinidae rove beetles were the most abundant families within the Coleoptera being large polyphagous predators with diversified generalist feeding habits commonly associated with open farmland where they provide biological control of pests such as slugs (Tillman et al. 2012). Linyphiidae money spiders contributed to the majority of individuals from the order Araneae, which are widespread due to their ballooning dispersal ability, allowing them to colonise field centres more rapidly than other spiders (Gallé et al. 2018). The Linyphiidae are small-bodied sheet weavers and provide biological control of pests such as aphids. Sphaeroceridae dung flies, Lonchopteridae pointed-wing flies and Phoridae hump-backed flies were most abundant within the Diptera. The majority are saprophagous and are involved in the decomposition of organic matter (Castelli et al. 2020). In the wet, cool upland grasslands studied here, this may help accelerate nutrient cycling, which could otherwise be slower via bacteria or fungal channels alone. Thus, the major invertebrate groups of upland grasslands, which were more taxa-rich under AES management, deliver key (agro)
Fig. 3 Distance-based redundancy analysis (dbRDA) community composition biplot for $50 \%$ of the most abundant and best-fitting plant species. Arrows represent constraining variables; ellipses represent $95 \%$ confidence intervals. Together, dbRDA 1 and dbRDA2 account for $17 \%$ of cumulative variation in full plant community composition. Latin names: $L$. perenne (ryegrass), H. Lanatus (Yorkshire fog), C. cristatus (crested dogstail), R. repens (common buttercup), T. repens (white clover), R. obtusifolius (broad-leaved dock), P. pratense (Timothy grass), A. pratensis (meadow foxtail), $P$. annua (annual meadowgrass), $A$. capillaris (common bent grass), C. fontanum (common mouseear), E. repens (common couch grass), B. perennis (daisy), Sphagnum (sphagnum moss), J. effusus (soft rush), N. stricta (mat grass), A. millefolium (yarrow).

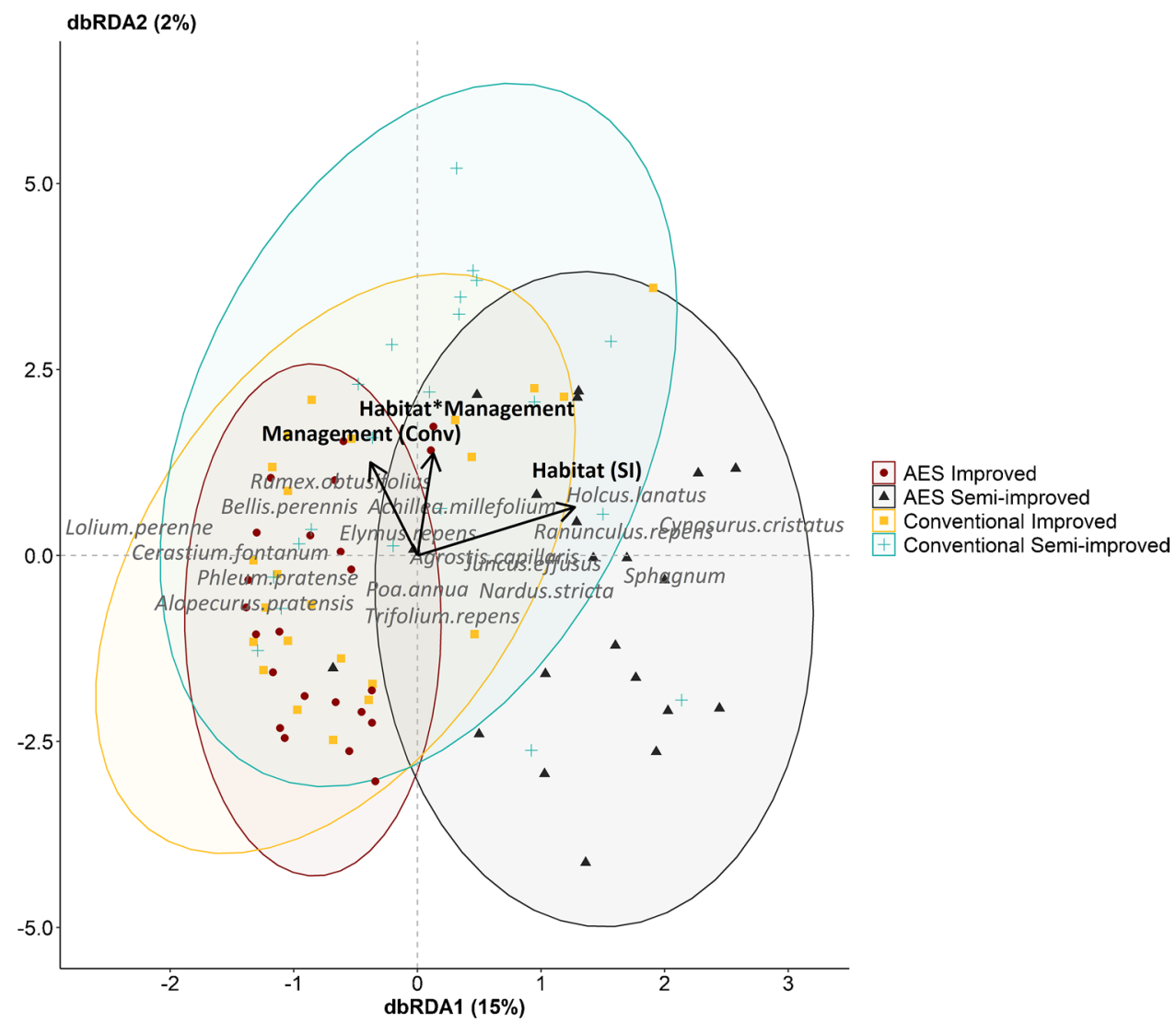


Table 3 Single best generalised linear mixed models for (a) invertebrate abundance, (b) invertebrate family richness, (c) rare $(<10 \%$ occurrence) invertebrate abundance and (d) rare invertebrate family richness. dbRDA 1 and 2 are distance-based redundancy analysis axes, and PNCM2 is axis 2 from the principal coordinates of neighbour matrices to account for spatial autocorrelation.

\begin{tabular}{llll}
\hline Model Distribution & $\beta \pm$ S.E & $\mathrm{Z}$ & $p$ \\
Explanatory variables & & & \\
\hline
\end{tabular}

\begin{tabular}{lcll}
\hline (a) Invertebrate abundance Negative binomial & & \\
Management, conventional & $-0.304 \pm 0.150$ & -2.032 & 0.042 \\
Habitat, semi-improved & $-0.239 \pm 0.164$ & -1.458 & 0.145 \\
dbRDA2 & $0.066 \pm 0.032$ & 2.033 & 0.042 \\
PCNM2 & $-2.510 \pm 0.488$ & -5.149 & $<0.001$ \\
Management*Habitat & $0.363 \pm 0.228$ & 1.592 & 0.111
\end{tabular}

(b) Invertebrate family richness Poisson

$\begin{array}{lccc}\text { Management, conventional } & -0.400 \pm 0.116 & -3.451 & <0.001 \\ \text { Habitat, semi-improved } & -0.150 \pm 0.120 & -1.254 & 0.210 \\ \text { dbRDA2 } & 0.037 \pm 0.026 & 1.440 & 0.150 \\ \text { PCNM2 } & -1.169 \pm 0.415 & -4.082 & <0.001 \\ \text { Management*Habitat } & 0.214 \pm 0.169 & 1.268 & 0.205\end{array}$

(c) Rare invertebrate abundance Negative binomial

$\begin{array}{lcll}\text { Management, conventional } & -0.839 \pm 0.333 & -2.158 & 0.012 \\ \text { Habitat, semi-improved } & 0.056 \pm 0.466 & 0.121 & 0.903 \\ \text { dbRDA1 } & -0.056 \pm 0.154 & -0.364 & 0.716 \\ \text { PCNM2 } & -4.408 \pm 1.242 & -3.548 & <0.001 \\ \text { Management*Habitat } & 0.296 \pm 0.532 & 0.556 & 0.578\end{array}$

(d) Rare invertebrate family richness Poisson

\begin{tabular}{lcll} 
Management, conventional & $-0.267 \pm 0.132$ & -2.030 & 0.042 \\
Habitat, semi-improved & $-0.117 \pm 0.134$ & -0.874 & 0.382 \\
dbRDA2 & $0.040 \pm 0.028$ & 1.456 & 0.145 \\
PCNM2 & $-1.527 \pm 0.438$ & -3.484 & $<0.001$ \\
Management*Habitat & $0.135 \pm 0.192$ & 0.700 & 0.484 \\
\hline
\end{tabular}

ecosystem services integral to the functioning of healthy farmland, reducing the need for chemical herbicidal and insecticidal inputs. Indeed, reduction of such inputs should be an integral component of AES measures (although it is not here), which in other studies have been associated with increased biodiversity (Fuentes-Montemayor et al. 2011; Anderson et al. 2013; Fritch et al. 2017; Humbert et al. 2021). We observed no interaction between habitat and management on invertebrate abundance or family-level richness suggesting AES management had a consistent effect on semi-improved and improved grasslands.

\section{Conclusions}

We demonstrate that AES management of upland grassland was associated with higher terrestrial invertebrate abundance and family-level richness compared to conventional management by maintaining more diverse swards with a higher coverage of native plant species. Without before-and-after data, we cannot conclude this relationship is causative, i.e. a direct consequence of management changes (Josefsson et al. 2020). This is because farmers might nominate less intense, lower productivity, more diverse and wetter fields for inclusion in AESs. Nevertheless, at the very least, we can conclude that AESs in upland grassland systems maintain, and thus offset declines in, terrestrial invertebrates seen in conventionally managed grasslands across the wider countryside. Although functional diversity was not considered here, invertebrates are bioindicators of ecosystem health and functionality; thus, higher relative taxonomic diversity is likely associated with ecosystem service delivery (biocontrol, nutrient cycling, etc.). This is relevant throughout the EU during the current period of CAP reform and is particularly pertinent in the UK postBrexit where the narrative around farming subsidies has shifted from production to environmental protection. Given the current biodiversity crisis, it is not sufficient to rely on islands or hotspots of semi-natural or semi-improved habitat to maintain species diversity. Focus should be on not just maintaining, but enhancing and thus restoring ecosystem service delivery in the wider countryside including improved grassland particularly in marginal or Less Favoured Areas such as the uplands.

Supplementary Information The online version contains supplementary material available at https://doi.org/10.1007/s13593-021-00738-4.

Acknowledgements We are grateful to farmers and landowners for granting permission to access land.

Authors' contributions AA and NR conceived the ideas and designed field data collection, AA collected the data, NR and AA designed statistical methods, and AA analysed the data. AA wrote the paper with extensive input from NR, ME and GR.

Funding This study was funded by the Department of Agriculture, Environment and Rural Affairs (DAERA), Northern Ireland.

Data and code availability The code for analysing the data and the data can be obtained from the corresponding author upon reasonable request.

\section{Declarations}

Ethics approval Not applicable.

Consent to participate Not applicable.

Conflict of interests The authors declare no competing interests.

Open Access This article is licensed under a Creative Commons Attribution 4.0 International License, which permits use, sharing, adaptation, distribution and reproduction in any medium or format, as long as you give appropriate credit to the original author(s) and the source, provide a link to the Creative Commons licence, and indicate if changes were made. The images or other third party material in this article are included in the article's Creative Commons licence, unless indicated 
otherwise in a credit line to the material. If material is not included in the article's Creative Commons licence and your intended use is not permitted by statutory regulation or exceeds the permitted use, you will need to obtain permission directly from the copyright holder. To view a copy of this licence, visit http://creativecommons.org/licenses/by/4.0/.

\section{References}

Acs S, Hanley N, Dallimer M et al (2010) The effect of decoupling on marginal agricultural systems: implications for farm incomes, land use and upland ecology. Land Use Policy 27:550-563. https://doi. org/10.1016/j.landusepol.2009.07.009

Altieri MA (1999) The ecological role of biodiversity in agroecosystems. Agric Ecosyst Environ 74:19-31. https://doi.org/10.1016/ S0167-8809(99)00028-6

Anderson A, Carnus T, Helden AJ et al (2013) The influence of conservation field margins in intensively managed grazing land on communities of five arthropod trophic groups. Insect Conserv Divers 6:201-211. https://doi.org/10.1111/j.1752-4598.2012. 00203.x

Arnott A, Riddell G, Emmerson M, et al. (2021) Upland grassland habitats and agri-environment schemes change soil microarthropod abundance. J Appl Ecol 1-10. https://doi.org/10.1111/13652664.13933

Barnosky AD, Matzke N, Tomiya S et al (2011) Has the Earth's sixth mass extinction already arrived? Nature 471:51-57. https://doi. org/10.1038/nature09678

Batáry P, Dicks LV, Kleijn D, Sutherland WJ (2015) The role of agrienvironment schemes in conservation and environmental management. Conserv Biol 29:1006-1016. https://doi.org/10.1111/ cobi.12536

Batáry P, Holzschuh A, Orci KM et al (2012) Responses of plant, insect and spider biodiversity to local and landscape scale management intensity in cereal crops and grasslands. Agric Ecosyst Environ 146:130-136. https://doi.org/10.1016/j.agee.2011.10.018

Berg Å, Cronvall E, Eriksson A et al (2019) Assessing agri-environmental schemes for semi-natural grasslands during a 5-year period: can we see positive effects for vascular plants and pollinators? Biodivers Conserv 28:3989-4005. https://doi.org/10.1007/ s10531-019-01861-1

Brooks ME, Kristensen K, van Benthem KJ et al (2016) glmmTMB Balances speed and flexibility among packages for zero-inflated generalized linear mixed modeling. Agric Ecosyst Environ 9:184-191

Butler SJ, Vickery JA, Norris K (2007) Farmland biodiversity and the footprint of agriculture. Science (80-) 315:381-384. https://doi. org/10.1126/science.1136607

Cardoso P, Erwin TL, Borges PAV, New TR (2011) The seven impediments in invertebrate conservation and how to overcome them. Biol Conserv 144:2647-2655. https://doi.org/10.1016/j.biocon. 2011.07.024

Caruso A, Öckinger E, Winqvist C, Ahnström J (2015) Different patterns in species richness and community composition between trees, plants and epiphytic lichens in semi-natural pastures under agri-environment schemes. Biodivers Conserv 24:1729-1742

Castelli LE, Gleiser RM, Battan-Horenstein M (2020) Role of saprophagous fly biodiversity in ecological processes and urban ecosystem services. Ecol Entomol 1-9. https://doi.org/10.1111/ een. 12849

Ceballos G, Ehrlich PR, Dirzo R (2017) Biological annihilation via the ongoing sixth mass extinction signaled by vertebrate population losses and declines. 6089-6096. https://doi.org/10.1073/pnas. 1704949114

Chapin FS III, Zavaleta ES, Eviner VT et al (2000) Consequences of changing biodiversity. Nature 405:234-242. https://doi.org/10. $1038 / 35012241$

Chinery M (1993) Collins field guide to the insects of Britain and Northern Europe, 3rd edn. HarperCollins

Cohen J (1988) Statistical power analysis for the behavioural sciences, 2nd edn. Lawrence Erlbaum, New Jersey

Concepción ED, Díaz M, Baquero RA (2008) Effects of landscape complexity on the ecological effectiveness of agri-environment schemes. Landsc Ecol 23:135-148. https://doi.org/10.1007/ s10980-007-9150-2

DAERA (2007) Countryside management scheme information booklet

DAERA (2018a) Statistical review of Northern Ireland agriculture 2018

DAERA (2019) Northern Ireland environmental statistics report 2019. Statistics (Ber) 78

DAERA (2018b) Nitrates action programme 2015-2018 \& phosphorus regulations health and safety advice for farm

Flexen M, O’Mahony D, McAdam JH (2013) Monitoring of farmland biodiversity indicators in Northern Ireland. In: Aspects of applied biology. pp 41-46

Foley JA, DeFries R, Asner GP et al (2005) Global consequences of land use. Science (80-) 309:570-574. https://doi.org/10.1126/ science. 1111772

Fox R, Oliver TH, Harrower C et al (2014) Long-term changes to the frequency of occurrence of British moths are consistent with opposing and synergistic effects of climate and land-use changes. J Appl Ecol 51:949-957. https://doi.org/10.1111/1365-2664.12256

Fraser MD, Davies DA, Vale JE et al (2009) Performance and meat quality of native and continental cross steers grazing improved upland pasture or semi-natural rough grazing. Livest Sci 123:7082. https://doi.org/10.1016/j.livsci.2008.10.008

Fritch RA, Sheridan H, Finn JA et al (2017) Enhancing the diversity of breeding invertebrates within field margins of intensively managed grassland: effects of alternative management practices. Ecol Evol 7:9763-9774. https://doi.org/10.1002/ece3.3302

Fuentes-Montemayor E, Goulson D, Park KJ (2011) The effectiveness of agri-environment schemes for the conservation of farmland moths: assessing the importance of a landscape-scale management approach. J Appl Ecol 48:532-542. https://doi.org/10.1111/j. 1365-2664.2010.01927.x

Gallé R, Happe AK, Baillod AB et al (2018) Landscape configuration, organic management, and within-field position drive functional diversity of spiders and carabids. J Appl Ecol 56:63-72. https:// doi.org/10.1111/1365-2664.13257

Haaland C, Naisbit RE, Bersier LF (2011) Sown wildflower strips for insect conservation: a review. Insect Conserv Divers 4:60-80. https://doi.org/10.1111/j.1752-4598.2010.00098.x

Hallmann CA, Sorg M, Jongejans E, et al. (2017) More than 75 percent decline over 27 years in total flying insect biomass in protected areas. PLoS One 12:. https://doi.org/10.1371/journal.pone.0185809

Humbert JY, Delley S, Arlettaz R (2021) Grassland intensification dramatically impacts grasshoppers: experimental evidence for direct and indirect effects of fertilisation and irrigation. Agric Ecosyst Environ 314:. https://doi.org/10.1016/j.agee.2021.107412

Humphreys RK, Puth MT, Neuhäuser M, Ruxton GD (2019) Underestimation of Pearson's product moment correlation statistic. Oecologia 189:1-7. https://doi.org/10.1007/s00442-018-4233-0

Jakobsson S, Plue J, Cousins SAO, Lindborg R (2019) Exploring the effects of pasture trees on plant community patterns. J Veg Sci 30:809-820. https://doi.org/10.1111/jvs.12771 
Jefferson RG (2005) The conservation management of upland hay meadows in Britain : a review. Grass Forage Sci 322-331. https:// doi.org/10.1111/j.1365-2494.2005.00489.x

Josefsson J, Hiron M, Arlt D et al (2020) Improving scientific rigour in conservation evaluations and a plea deal for transparency on potential biases. Conserv Lett 13:1-8. https://doi.org/10.1111/ conl.12726

Kampmann D, Lüscher A, Konold W, Herzog F (2012) Agri-environment scheme protects diversity of mountain grassland species. Land Use Policy 29:569-576. https://doi.org/10.1016/j.landu sepol.2011.09.010

Kleijn D, Baquero RA, Clough Y et al (2006) Mixed biodiversity benefits of agri-environment schemes in five European countries. Ecol Lett 9:243-254. https://doi.org/10.1111/j.1461-0248.2005. 00869.x

Kleijn D, Sutherland WJ (2003) How effective are European schemes in and promoting conserving biodiversity? J Appl Ecol 40:947-969. https://doi.org/10.1111/j.1365-2664.2003.00868.x

Kovács-Hostyánszki A, Korösi Á, Orci KM et al (2011) Set-aside promotes insect and plant diversity in a Central European country. Agric Ecosyst Environ 141:296-301. https://doi.org/10.1016/j. agee.2011.03.004

Lennox GD, Armsworth PR (2011) Suitability of short or long conservation contracts under ecological and socio-economic uncertainty. Ecol Modell 222:2856-2866. https://doi.org/10.1016/j.ecolmodel. 2011.04.033

Loreau NS, Inchausti P et al (2001) Biodiversity and ecosystem functioning: current knowledge and future challenges. Science (80-) 294:804-808. https://doi.org/10.1126/science.1064088

Macgregor CJ, Williams JH, Bell JR, Thomas CD (2019) Moth biomass increases and decreases over 50 years in Britain. Nat Ecol Evol 3:1645-1649. https://doi.org/10.1038/s41559-019-1028-6

Marrs RH, Philips JDP, Todd P., et al. (2004) Control of Molinia caerulea on upland moors. J Appl Ecol 398-411. https://doi.org/10. 1111/j.0021-8901.2004.00901.x

Mazerolle MJ (2019) AICcmodavg: model selection and multimodel inference based on (Q)AIC(c)

NPMS (2015) Survey guidance notes, 2nd edn. Acanthus Press

Office for National Statistics (2015) UK natural capital land cover in the UK

Oksanen J, Blanchet FG, Friendly M, et al. (2019) vegan: community ecology package

Outhwaite CL, Gregory RD, Chandler RE et al (2020) Complex long-term biodiversity change among invertebrates, bryophytes and lichens. Nat Ecol Evol 4:384-392. https://doi.org/10.1038/ s41559-020-1111-z

Prather CM, Pelini SL, Laws A et al (2013) Invertebrates, ecosystem services and climate change. Biol Rev 88:327-348. https://doi. org/10.1111/brv.12002
R Core Team (2018) R: a language and environment for statistical computing

Reid N, McDonald RA, Montgomery WI (2007) Mammals and agrienvironment schemes: hare haven or pest paradise? J Appl Ecol 44:1200-1208. https://doi.org/10.1111/j.1365-2664.2007.01336.x

Roberts MJ (1995) Collins field guide to the spiders of Britain and Northern Europe. HarperCollins

Sánchez-Bayo F, Wyckhuys KAG (2019) Worldwide decline of the entomofauna: a review of its drivers. Biol Conserv 232:8-27. https://doi.org/10.1016/j.biocon.2019.01.020

Smith J, Potts S, Eggleton P (2008) The value of sown grass margins for enhancing soil macrofaunal biodiversity in arable systems. Agric Ecosyst Environ 127:119-125. https://doi.org/10.1016/j. agee.2008.03.008

Soliveres S, Van Der Plas F, Manning P et al (2016) Biodiversity at multiple trophic levels is needed for ecosystem multifunctionality. Nature 536:456-459. https://doi.org/10.1038/nature19092

Steiner M, Öckinger E, Karrer G et al (2016) Restoration of seminatural grasslands, a success for phytophagous beetles (Curculionidae). Biodivers Conserv 25:3005-3022. https://doi.org/10. 1007/s10531-016-1217-4

Thomas JA, Telfer MG, Roy DB et al (2004) Comparative losses of British butterflies, birds, and plants and the global extinction crisis. Science 303:1879-1881. https://doi.org/10.1126/science. 1095046

Tillman PG, Smith HA, Holland JM (2012) Cover crops and related methods for enhancing agricultural biodiversity and conservation biocontrol : successful case studies. In: Gurr GM, Wratten SD, Snyder WE, Read DMY (eds) Biodiversity and insect pests: key issues for sustainable management, 1st edn. John Wiley \& Sons, Ltd, pp 309-328

Tilman D (1999) Global environmental impacts of agricultural expansion: the need for sustainable and efficient practices. Proc Natl Acad Sci 96:5995-6000. https://doi.org/10.1073/pnas.96.11.5995

Tscharntke T, Klein AM, Kruess A et al (2005) Landscape perspectives on agricultural intensification and biodiversity - ecosystem service management. Ecol Lett 8:857-874. https://doi.org/10.1111/j. 1461-0248.2005.00782.x

Woodcock BA, Vogiatzakis IN, Westbury DB et al (2010) The role of management and landscape context in the restoration of grassland phytophagous beetles. J Appl Ecol 47:366-376. https://doi.org/10. 1111/j.1365-2664.2010.01776.x

Zuur AF, Ieno EN, Elphick CS (2010) A protocol for data exploration to avoid common statistical problems. Methods Ecol Evol 1:3-14. https://doi.org/10.1111/j.2041-210x.2009.00001.x

Publisher's note Springer Nature remains neutral with regard to jurisdictional claims in published maps and institutional affiliations. 